\title{
EVALUASI KINERJA PENDIDIK DAN TENAGA KEPENDIDIKAN DAN PROSES PEMBELAJARAN PENDIDIKAN ISLAM DI INDONESIA
}

\author{
Dr. Umi Faizah, S. Ag., M. Pd \\ Sekolah Tinggi Pendidikan Islam (STPI) Bina Insan Mulia - Yogyakarta \\ umifaizah74@gmail.com
}

\begin{abstract}
Evaluation is a component of education that must be carried out systematically and planned as a measure of the success of the education and learning process. The author limits the discussion of evaluation of Islamic education in this article to 2 aspects, namely aspects of teacher performance and the learning process. The main problems that are often discussed related to aspects of teacher performance are the problems of teacher qualifications and competencies and the implementation of learning. While the problems faced in the learning process generally occur because of the low skill of mastering the latest technology also becomes a serious problem in the fast-paced information age. If the government previously determined four basic competencies that must be mastered by teachers in addition to a minimum educational qualification of S1 or D4, it is necessary to seriously study the offer of one new competency that must be possessed by teachers and education personnel, namely Technology Mastery Competence.
\end{abstract}

Keywords: evaluation, teacher performance, learning process

\begin{abstract}
ABSTRAK
Evaluasi merupakan seatu komponen pendidikan yang harus dilaksanakan secara sistematis dan terencana sebagai alat ukur keberhasilan proses pendidikan dan pembelajaran. Penulis membatasi pembahasan evaluasi pendidikan Islam dalam artikel ini pada 2 aspek yaitu aspek kinerja guru dan proses pembelajaran. Permasalahan utama yang kerap dibicarakan terkait aspek kinerja guru adalah masalah kualifikasi dan kompetensi Guru dan pelaksanaan pembelajaran. Sedangkan persoalan yang dihadapi dalam proses pembelajaran umumnya terjadi karena rendahnya skill penguasaan teknologi terkini menjadi permasalahan serius pula di era informasi yang serba cepat. Jika sebelumnya pemerintah menetapkan 4 kompetensi dasar yang harus dikuasai Guru disamping kualifikasi pendidikan minimal S1 atau D4, maka perlu dikaji secara serius tawaran satu kompetensi baru yang harus dimiliki Guru dan tenaga kependidikan yaitu Kompetensi Penguasaan Teknologi.
\end{abstract}

Kata Kunci: Evalusi, kinerja guru, proses pembelajaran 
A.

\section{B. PENDAHULUAN}

Ada ungkapan di tengah masyarakat kita, bahwa musuh dari kesempurnaan adalah merasa baik. Hal ini bisa dibenarkan mengingat merasa baik seringkali menjadikan seseorang, baik pribadi atau kelompok tak lagi merasa perlu berbenah. Selaras dengan hal itu Umar bin Khatab pernah menyatakan, "hasibu qobla an tuhasabu" (hitunglah diri kalian sebelum datang hari perhitungan). Perilaku bermuhasabah dan mengevaluasi diri dengan tujuan berhati-hati dalam bertindak dan terus melalukan perbaikan telah menjadi akhlak orang-orang utama dalam perjalanan sejarah. Tak ada satupun di dunia ini yang tak mengalami perubahan kecuali perubahan itu sendiri. Keniscayaan tersebutlah yang menuntut pentingnya upaya muhasabah dan evaluasi.

Dalam konteks pendidikan Islam, evaluasi merupakan salah satu komponen dari sistem pendidikan yang harus dilakukan secara sistematis dan terencana sebagai alat untuk mengukur keberhasilan atau target yang akan dicapai dalam proses pendidikan dan pembelajaran (Ramayulis, 2008: 220). Zainal Arifin menyatakan evaluasi adalah suatu proses yang sistematis dan berkelanjutan untuk menentukan kualitas (nilai dan arti) dari sesuatu, berdasarkan pertimbangan dan kriteria tertentu untuk membuat suatu keputusan (Arifin, 2012: 8). Dari pengertian tersebut evaluasi pendidikan bisa pula dimaknai segala bentuk penilaian, pengukuran, penafsiran yang sistematis dan objektif atas tujuan atau target yang telah dicapai dalam proses pendidikan.
Landasan evaluasi pendidikan Islam di Indonesia adalah UUD 45 pasal 31 yang diterjemahkan dalam UndangUndang No 20 tahun 2003 tentang Sistem Pendidikan nasional. Badan Nasional Standar Pendidikan kemudian merumuskan 8 standart yang menjadi acuan gerak pelaksanaan evaluasi pendidikan secara menyeluruh.

Dalam pelaksanaannya 8 standart yang meliputi: 1) standart isi; 2) standar proses; 3) standar kompetensi lulusan; 4) standar pendidik dan tenaga kependidikan; 5) standar sarana prasarana; 6) standart pengelolaan; 7) standart pembiayaan pendidikan; dan 8) standar evaluasi/pendidikan tersebut diikuti dengan diterbitkannya beberapa Permendiknas dan Peraturan Menteri Agama (PMA). Kegiatan evaluasi semestinya dilakukan mengacu pada landasan undang-undang serta menyeluruh meliputi 8 standart yang telah dirumuskan BSNP, namun dalam makalah ini penulis akan membatasi pembahasan evaluasi pendidikan Islam pada 2 aspek yang seringkali menjadi isu sentral dan hangat. Kedua aspek yang menjadi fokus makalah ini adalah aspek kinerja guru dan proses pembelajaran.

\section{POTRET PENDIDIKAN ISLAM DI INDONESIA}

Perjuangan umat Islam di Indonesia untuk membangun citra kesetaraan dengan pendidikan umum sebenarnya telah lama dimulai, namun hingga saat ini pendidikan Islam masih saja dikesankan sebagai pendidikan kelas dua di tanah air ini (Damopoli, 2007: 54). Berikut ini akan diuraikan beberapa perspektif potret pendidikan Islam di Indonesia yang tampak pada aspek 
kinerja pendidik, proses pembelajaran dan kelembagaannya.

\section{Kinerja Pendidik}

Pengertian kinerja dapat dipahami sejauh mana seseorang telah memainkan perannya dalam melaksanakan strategi organisasi, baik dalam mencapai sasaran-sasaran khusus yang berhubungan dengan peranan perseorangan, dan atau dengan memperlihatkan kompetensikompetensi yang dinyatakan relevan bagi organisasi apakah dalam suatu peranan tertentu, atau secara lebih umum (Mitrani, 1995: 131). Menurut Didi Pianda kinerja adalah sebuah kata dalam bahasa Indonesia dari kata dasar "kerja" yang bermakna prestasi atau bisa pula berarti hasil kerja (Pianda, 2018: 11). Dalam hubungannya dengan dunia pendidikan, maka kinerja guru dapat didefinisikan sebagai sejauh mana seorang guru bekerja secara maksimal sesuai dengan kemampuan yang dimilikinya dalam upaya mencapai tujuan institusional. Kemampuan seorang guru akan terlihat pada saat mengajar yang dapat diukur dari kompetensi mengajarnya.

Pendidik selalu menjadi sorotan utama dalam isu pendidikan dari masa ke masa. Hal ini dikarenakan pendidik adalah ujung tombak penentu keberhasilan pendidikan. Di antara isu-isu pendidikan yang lain, masalah kinerja pendidik selalu mendapat sorotan utama. Berbagai program dilaksanakan dengan harapan kinerja pendidik akan terus dapat ditingkatkan, yang pada akhirnya kualitas pendidikan anak bangsa pun akan meningkat pula. Beberapa tokoh merumuskan tentang indikator penilaian kinerja salah satunya adalah rumusan kinerja oleh Uno dan Lamatenggo dalam buku Teori Kinerja dan Pengukurannya.

Kinerja seseorang (termasuk guru) dapat diukur melalui lima indikator pokok sebagai berikut: (Uno, 2012: 65)

1. Kualitas kerja. Indikator ini berkaitan dengan kualitas kerja guru dalam menguasai segala sesuatu berkaitan dengan persiapan perencanaan program pembelajaran dan penerapan hasil penelitian dalam pembelajaran di kelas.

2. Kecepatan/ketetapan kerja. Indikator ini berkaitan dengan ketepatan kerja guru dalam menyesuaikan materi ajar dengan karakteristik yang dimiliki peserta didik dan penyelesaian program pengajaran sesuai dengan kalender akademik.

3. Inisiatif dalam kerja. Indikator ini berkaitan dengan inisiatif guru dalam penggunaan model pembelajaran yang variatif sesuai materi pelajaran dan penggunaan berbagai inventaris sekolah dengan bijak.

4. Kemampuan kerja. Indikator ini berkaitan dengan kemampuan guru dalam memimpin keadaan kelas agar tetap kondusif, pengelolaan kegiatan belajar mengajar, dan penilaian hasil belajar peserta didik.

5. Komunikasi. Indikator ini berkaitan dengan komunikasi yang dilakukan guru dalam proses 
layanan bimbingan belajar dengan siswa yang kurang mampu mengikuti pembelajaran dan terbuka dalam menerima masukan untuk perbaikan pembelajaran.

Salah satu program yang telah diluncurkan pemerintah terkait upaya peningkatan kinerja guru/pendidik adalah program sertifikasi pendidik sejak 2007 lalu. Setelah beberapa tahun berjalan, ternyata program sertifikasi dinilai tidak memberikan dampak yang signifikan terhadap upaya peningkatan kinerja Guru/pendidik sebagaimana yang diharapkan (Widyawati, 2012: 3). Hal ini dibuktikan dengan penelitian yang dilakukan oleh Amat Jaedun dalam barizi dan Idris (2010) tentang evaluasi kinerja guru pasca sertifikasi. Berdasarkan hasil penelitian dapat disimpulkan bahwa usaha pemerintah itu akan sia-sia manakala kinerja guru yang telah disertifikasi (guru profesional) tidak menjadi lebih baik bila dibandingkan dengan kinerja guru sebelum disertifikasi. Hal ini dapat terjadi bila setelah disertifikasi, kinerja guru menurun karena merasa tidak lagi dinilai, dan tidak ada sanksi.

Tabel tentang kinerja Guru tersertifikasi di bawah ini semakin memberi gambaran menurunnya inisiatif kerja Guru penerima sertifikasi dibandingkan mereka yang belum tersertifikasi (Koswara, 2016: $65)$.

\section{Tabel 1 Kompetensi Guru}

\begin{tabular}{|l|c|c|c|}
\hline Indikator & $\begin{array}{c}\text { Guru Belum } \\
\text { Sertifikasi }\end{array}$ & $\begin{array}{c}\text { Guru Sudah } \\
\text { Sertifikasi }\end{array}$ & Rata-Rata \\
\hline Kualitas Kerja & 3,22 & 4,19 & 3,89 \\
\hline Ketepatan Kerja & 3,52 & 4,22 & 4,02 \\
\hline Inisiatif Kerja & 4,16 & 4,12 & 4,13 \\
\hline Kemampuan Kerja & 3,92 & 4,36 & 4,22 \\
\hline Komunikasi & 3,56 & 4,15 & 3,95 \\
\hline Rata-rata & $\mathbf{3 , 6 8}$ & $\mathbf{4 , 2 1}$ & $\mathbf{4 , 0 4}$ \\
\hline
\end{tabular}

Dari tabel di atas dapat diketahui kompetensi Guru yang sudah tersertifikasi mengalami peningkatan pada empat indikator; kualitas kerja, ketepatan kerja, kemampuan kerja, komunikasi, namun mengalami penurunan pada indikator inisiatif kerja.

Hal lain yang menjadi sorotan dalam kriteria kinerja guru/pendidik adalah kualifikasi dan kompetensi pendidik dan tenaga kependidikan sebagaimana tertuang dalam permendiknas nomor 16 tahun 2007 tentang kualifikasi dan kompetensi guru/tenaga kependidikan sebagai penjabaran dari Undang-Undang nomor 14 tahun 2005 tentang Guru dan Dosen.

Undang-undang Nomor 14 Tahun 2005 tentang Guru dan Dosen dan Peraturan Pemerintah Nomor 74 Tahun 2008 tentang Guru mewajibkan guru memiliki kualifikasi akademik minimum lulusan D4 atau S1, kompetensi dasar yang meliputi; kompetensi pedagogik, kompetensi kepribadian, 
kompetensi social dan kompetensi professional. Keempat kompetensi dasar inilah yang kemudian dikembangkan dan dijabarkan dalam rumusan kriteria penilaian program Penilaian Kinerga Guru (PKG). Sebagai pelengkap standart kualifikasi dan kompetensi guru pun dituntut memiliki sertifikat pendidik.

Pada Pasal 4 Peraturan Pemerintah Nomor 74 Tahun 2008 ditegaskan bahwa sertifikat pendidik bagi guru diperoleh melalui program pendidikan profesi yang diselenggarakan oleh perguruan tinggi yang memiliki program pengadaan tenaga kependidikan yang terakreditasi, baik yang diselenggarakan oleh Pemerintah maupun masyarakat. Pendidikan tersebut dilaksanakan setelah jenjang program S-1 (Sarjana).

Laporan sumber daya Ristekdikti di tahun 2017 menyebutkan saat ini ada lebih dari 450 LPTK, dengan jumlah mahasiswa lebih dari 1.5 juta. Dari angka tersebut diperkirakan lulusan sarjana kependidikan sekitar 300.000 orang per tahun. Sedangkan kebutuhan guru hanya sekitar 40.000 orang per tahun. Kita diancam over supply. Rupanya hukum ekonomi juga berlaku di sektor pendidikan. Sejak program sertifikasi guru diselenggarakan tahun 2007 dan kemudian tahun 2008 guru mulai mendapatkan tunjangan profesi, maka guru menjadi profesi yang semakin seksi. Masyarakat beramairamai ingin menjadi guru. Lalu peminat masuk LPTK meningkat tajam. Tanpa menyia-nyiakan kesempatan, fenomena ini lalu ditangkap oleh penyelenggara pendidikan guru. Usulan pendirian LPTK dan prodi kependidikan melonjak tajam.

Lonjakan jumlah peminat yang memasuki prodi kependidikan tersebut semakin mempersulit sistem control terhadap mutu proses penyelenggaraan pendidikan dan lulusan LPTK. Ironi ini semakin tampak jika kita melihat data yang dikeluarkan Global Teacher Status Index tahun 2008. dalam penelitian yang dilakukan Varkey Foundation, University of Sussex, dan National Institute of Economic and Social Research (NIESR). Laporan berjudul Global Teacher Status (GTS) Index 2018 itu memaparkan hubungan antara status guru di masyarakat dan hasilnya terhadap pendidikan.

Tabel 2 : GTSI, Teacher

Salaries and PISA Ranking

\begin{tabular}{|c|c|c|c|c|}
\hline $\begin{array}{l}\mathrm{N} \\
\mathrm{O}\end{array}$ & $\begin{array}{c}\text { COUNTR } \\
Y\end{array}$ & $\begin{array}{c}\text { INDEX } \\
\text { RANKI } \\
\text { NG }\end{array}$ & $\begin{array}{c}\text { ACTUAL } \\
\text { TEACHER } \\
\text { SALARY } \\
\text { (USD,PPP,ADJUS } \\
\text { TED) }\end{array}$ & $\begin{array}{c}\text { PISA } \\
\text { RANKING } \\
\text { (1-35 } \\
\text { SCORE) }\end{array}$ \\
\hline 1 & China & 100.0 & 12.210 & 7 \\
\hline 2 & Malaysia & 93.3 & 18.120 & $\begin{array}{c}\text { NOT } \\
\text { AVAILABL } \\
\text { E }\end{array}$ \\
\hline 3 & Taiwan & 70.2 & 40.821 & 3.5 \\
\hline 4 & Russia & 65.0 & 5.923 & 15 \\
\hline 5 & $\begin{array}{l}\text { Indonesi } \\
\text { a }\end{array}$ & 62.1 & 14.408 & 27 \\
\hline 6 & Korea & 61.2 & 33.141 & 6 \\
\hline 7 & Turkey & 59.1 & 30.303 & 25 \\
\hline 8 & India & 58.0 & 21.608 & $\begin{array}{c}\text { NOT } \\
\text { AVAILABL } \\
\text { E }\end{array}$ \\
\hline 9 & $\begin{array}{l}\text { New } \\
\text { Zealand }\end{array}$ & 56.0 & 33.099 & 11 \\
\hline 10 & $\begin{array}{l}\text { Singapor } \\
\text { e }\end{array}$ & 51.7 & 50.249 & 1 \\
\hline 11 & Canada & 49.9 & 43.715 & 3.5 \\
\hline 12 & Greece & 48.3 & 21.481 & 23 \\
\hline 13 & United & 46.6 & 31.845 & 12 \\
\hline
\end{tabular}




\begin{tabular}{|c|c|c|c|c|}
\hline & Kingdom & & & \\
\hline 14 & $\begin{array}{l}\text { Swirzerla } \\
\text { nd }\end{array}$ & 43.7 & 77.491 & 10 \\
\hline 15 & Panama & 42.0 & 16.000 & $\begin{array}{c}\text { NOT } \\
\text { AVAILABL } \\
\text { E }\end{array}$ \\
\hline 16 & $\begin{array}{l}\text { United } \\
\text { States }\end{array}$ & 39.7 & 44.229 & 18 \\
\hline 17 & Finland & 38.0 & 40.491 & 5 \\
\hline 18 & Japan & 37.4 & 31.461 & 2 \\
\hline 19 & Egypt & 34.8 & 6.592 & $\begin{array}{c}\text { NOT } \\
\text { AVAILABL } \\
\text { E }\end{array}$ \\
\hline 20 & France & 33.7 & 33.675 & 14 \\
\hline 21 & Germany & 33.4 & 65.396 & 8.5 \\
\hline 22 & Chile & 33.1 & 20.890 & 24 \\
\hline 23 & Portugal & 32.9 & 35.519 & 13 \\
\hline 24 & $\begin{array}{l}\text { Netherla } \\
\text { nd }\end{array}$ & 32.2 & 43.743 & 8.5 \\
\hline 25 & Peru & 31.1 & 12.478 & 29 \\
\hline 26 & Colombia & 30.3 & 18806 & 26 \\
\hline 27 & Spain & 29.1 & 47.864 & 16 \\
\hline 28 & Uganda & 25.1 & 4.205 & $\begin{array}{c}\text { NOT } \\
\text { AVAILABL } \\
\text { E }\end{array}$ \\
\hline 29 & Hungary & 24.4 & 16.241 & 20 \\
\hline 30 & $\begin{array}{l}\text { Czech } \\
\text { Republic }\end{array}$ & 23.9 & 18.859 & 17 \\
\hline 31 & $\begin{array}{l}\text { Argentin } \\
\text { a }\end{array}$ & 23.6 & 10.371 & 22 \\
\hline 32 & Ghana & 18.9 & 7.249 & $\begin{array}{c}\text { NOT } \\
\text { AVAILABL } \\
\text { E }\end{array}$ \\
\hline 33 & Italy & 13.6 & 33.630 & 19 \\
\hline 34 & Israel & 6.6 & 22.175 & 21 \\
\hline 35 & Brazil & 1.0 & 12.993 & 28 \\
\hline
\end{tabular}

Dari data tabel di atas diperoleh fakta bahwa pendapatan/gaji yang tinggi tidak selalu diikuti peningkatan rangking PISA. PISA merupakan sistem ujian yang diinisasi oleh Organisation for Economic Cooperation and Development (OECD), untuk mengevaluasi sistem pendidikan dari 72 negara di seluruh dunia. Setiap tiga tahun, siswa berusia 15 tahun dipilih secara acak, untuk mengikuti tes dari tiga kompetensi dasar yaitu membaca, matematika dan sains. PISA mengukur apa yang diketahui siswa dan apa yang dapat dia lakukan (aplikasi) dengan pengetahuannya. Dibandingkan dengan China, salary Pendidik di Indonesia relatif lebih besar, namun rangking PISA kita jauh tertinggal di bawah China yang menempati posisi ke 7 .

Belum lagi jika dilihat dari Human Development Index tahun 2018 dimana Indonesia masih menempati posisi 108 dari 187 negeara di dunia. Di kawasan ASEAN saja kita masih tertinggal dari Singapura (9), Brunei (30), Malaysia (63) dan Thailand (89). Sementara di tigkat global Norwegia masih memimpin di peringkat teratas disusul Australia (2), Swiss (3), Belanda (4), Amerika Serikat (5), Jerman (6), Selandia Baru (7), Kanada (8), Singapura (9) dan Denmark (10). Hal ini bisa ditafsirkan pendidikan di Indonesia belum sepenuhnya mampu mengangkat harkat martabat ke tingkat yang lebih baik.

Menyadari sepenuhnya bahwa kualitas pendidikan lebih banyak ditentukan oleh kualifikasi dan kompetensi guru dan tenaga kependidikan sebagai ujung tombak dan ruh pendidikan itu sendiri, dua kementrian yang langsung bersinggungan dengan hal ini, yaitu Kementrian Pendidikan dan Kebudayaan serta Kementrian Agama terus berupaya melakukan berbagai terobosan. Penguatan dan peningkatan kualifikasi akademik melalui jalur perkuliahan maupun peningkatan kompetensi guru dan tenaga kependidikan melalui 
program-program diklat, kursus, workshop terus dilakukan. Program sertifikasi, berbagai ajang kompetisi antar Guru dan tenaga kependidikan, serta pemberian award penghargaan kepada Guru dan tenaga kependidikan berprestasi dari tingkat daerah hingga nasional terus digalakkan untuk memotivasi dan mendongkrak kinerja guru-guru kita.

\section{PROSES PEMBELAJARAN}

Proses kunci kegiatan pendidikan tinggi adalah pengajaran dan pembelajaran (teaching and learning). Oleh karenanya ketrampilan yang masuk dalam salah satu kompetensi utama pendidik ini harus mendapat perhatian lebih jika kita berharap peningkatan kualitas pendidikan anak bangsa. Beberapa permasalahan yang hingga saat ini masih menjadi kendala dalam proses pembelajaran antara lain :

\section{Lemahnya Penguasaan Metode dan Media Terbaru}

Model-model pembelajaran, lemahnya inisiatif Guru kita dalam penguasaan metodologi dan pendekatan pembelajaran serta penggunaan media kekinian masih menjadi kendala peningkatan proses pembelajaran di sekolah kita saat ini.

Pembelajaran

konstruktivisme, e-learning, heutagogy dan yang terbaru dan sedang popular saat ini pembelajaran Blended Learning yang lebih memberi kebebasan siswa bereksplorasi sesuai kecepatan dan kemampuan belajar perlu terus dikembangkan dalam proses pembelajaran (Noer, tth).

Kehadiran IT sebagai dalam dunia pendidikan kita, khususnya dalam proses pembelajaran Guru dan murid harus disikapi secara pro aktif dan positif. Dampak negative yang menjadi keniscayaan kehadiran teknologi dalam pendidikan tidak boleh menutup dan menghilangkan pengaruh positifnya yang lebih besar. Patut disayangkan jika seorang guru enggan mengupgrade kemampuannya dalam mempelajari model-model pembelajaran mutakhir, serta penggunaan metode dan media terbaru dalam mendidik anak didiknya hanya dikarenakan asumsi dan kekhawatiran pengaruh dan dampak buruk teknologi bagi perkembangan anak didiknya.

Rabindranath Tagore pernah mengungkapkan, "Obor yang padam tak kan mungkin menyalakan obor lainnya." Pernyataan ini jika dianalogikan dalam permasalahan guru dan proses pembelajaran kita seolah mengingatkan keras, betapa hebatnya potensi seorang guru jika ia tak terus belajar dan mengembangkan diri (menyalakan obor) maka tak mungkin dirinya mampu menyalakan motivasi belajar anak didiknya. Andi Prastowo menekankan hal ini dalam pernyataannya, "Kapan lagi pendidikan kita akan maju jika para pendidik sudah mengalami kemiskinan motivasi untuk mengembangkan diri?" (Prastowo, 2011: 13). Terlebih di era global, era informasi, era industry 4.0 ini siapapun termasuk para guru yang tidak terus bertumbuh dan siap 
menghadapi perubahan yang makin cepat, maka ia akan terdisrupsi.

Kita bisa belajar dari teori yang dikemukakan oleh Clayton M. Christensen. Teori disruption sebenarnya telah dikemukakan oleh Christensen sejak tahun 1997, jauh sebelum maraknya bisnis online apalagi jasa layanan seperto Go-Jek, Grab dan Uber. Dan tanpa diduga, bagai serangan fajar tahu-tahu banyak perusahaan besar tumbang oleh musuh yang tak terlihat (Kasali, 2017: 119). Guru dan seluruh masyarakat pendidikan harus bersegera kini. Guru tak bisa hanya berbangga dengan pengalaman panjang mengajarnya selama bertahun-tahun. Kini anak-anak milenial tak butuh waktu lama untuk mempelajari hal-hal baru. Jika guru tidak merancang program pembelajarannya dengan baik, maka bisa jadi ia akan ditinggalkan muridmuridnya.

\section{Pembelajaran Teacher Centre}

Meski telah memahami berbagai perkembangan terbaru dalam hal kebijakan sampai praktik metodologi pembelajaran terkini yang lebih mengedepankan pembelajaran berpusat siswa (student centre), namun dalam praktiknya guru-guru kita masih sulit meninggalkan gaya pembelajaran yang berpusat pada Guru (Teacher centre). Zaman telah berubah, teoriteori pendidikan dan pembelajaran telah mengalami perkembangan yang sangat jauh, namun praktik mengajar Guru yang cenderung menjadikan dirinya sebagai aktor tunggal pembelajaran nyata tak mudah diubah. Masih banyak guru khususnya ditingkat pendidikan dasar dan menengah yang menjadikan dirinya sebagai satu-satunya sumber belajar anak didiknya.

Dualisme antara ranah pengetahuan dan kontradiksinya dengan ranah aplikasi di lapangan dalam dunia pendidikan sebenarnya telah sangat lama menjadi perhatian dan pemikiran para pakar pendidikan dan filosof masa lalu. Dewey dalam bukunya Sembodo Ardi menyebut penguasaan pengetahuan murid dibawah ototitas Guru harus disudahi dengan memadukannya melalui kegiatan pengembangan diri secara mandiri di bawah bimbingan inisiatif anak didik. Manipulasi Guru atas anak didik semestinya diminimalkan dan pengembangan anak didik melalui aktivitas dioptimalkan (Widodo, 2015: 153).

\section{Classroom Based Education}

Makna class dalam kamus besar bahasa Inggris-Indonesia (KBBI) adalah golongan, pelajaran, kelas, dan sekolah. Pengertian kelas dalam PTK adalah sekelompok peserta didik yang sedang belajar. Siswa yang belajar itu tidak hanya terbatas di dalam sebuah ruangan yang tertutup saja, tetapi juga ketika anak sedang melakukan karyawisata, di laboratorium, di rumah atau di tempat lain, ketika siswa sedang mengerjakan tugas yang diberikan oleh guru. Dengan demikian makna kelas di sini tidak hanya bersifat fisik, tetapi lebih bersifat fungsional, sehingga dimanapun tempatnya jika 
memenuhi persyaratan dalam proses pembelajaran dinamakan kelas. Sayangnya dalam banyak kalangan dan kesempatan makna class ini disempitkan sekedar sebagai ruangan tempat belajar.

Penyempitan makna Class based Education menjadi Classroom based Teaching ini tentu saja berdampak besar dalam pengembangan pendidikan pada umumnya. Sehingga wajarlah saat ini proses pembelajaran di sekolahsekolah kita masih didominasi pembelajaran di dalam kelas. Bahkan di sekolah-sekolah pedesaan yang relatif masih memiliki ruang outdoor (halaman \& lingkungan) yang luas untuk dieksplorasi dalam pembelajaran dengan siswa, proses pembelajaran tetap didominasi aktivitas duduk dan sedikit gerak di dalam ruangan kelas. Pembelajaran Classroom based Teaching seolah menjadi pilihan tunggal bagi dunia persekolahan kita. Di tingkat PAUD dan pendidikan dasar dimana anak didik sesungguhnya masih membutuhkan eksplorasi gerak motorik kasar dalam porsi yang besar, penerapan Classroom based Teaching ini tentu banyak menimbulkan masalah. Anak kurang gerak, miskin pengalaman lapangan, dan akhirnya terkungkung dalam imajinasi verbalis yang cenderung hanya membangun pengetahuan secara teoritis semata.

Dampak lain penerapan Classroom based Teaching ini adalah lemahnya ketrampilan guru dalam pengelolaan kelas, dimana kelas disini seharusnya tidak saja dimaknai secara fisik namun lebih kepada aspek anak didik sebagai pribadi yang unik serta berbagai factor lainnya.

\section{Evaluasi Pendidikan yang Gagal}

Pelaksanaan evaluasi

pendidikan yang lebih mengutamakan angka-angka (nilai kuantitas) dibandingkan aspek moral semakin menjadikan wajah pendidikan kita tercoreng dan bopeng-bopeng. Evaluasi yang di lakukan Guru di ruang kelas hingga ujian akhir nasional seolah hanya menekankan dan mengarahkan anak didik menjadi manusia tanpa jiwa. Sedari awal anak didik sudah diarahkan dan difokuskan untuk lebih mengutamakan bidang studi tertentu yang diujikan secara nasional, sementara mata pelajaran lain cenderung diabaikan dan terpinggirkan.

Penetapan standar nasional capaian pendidikan semestinya disesuaikan pula dengan kondisi sosio-kultural serta geografis suatu daerah. Sehingga jika pemerintah dalam hal ini melalui Departemen Pendidikan dan Kebudayaan atau Kementrian Agama menetapkan standart capaian hasil pembelajaran bukanlah serta merta seluruh daerah dengan keragaman latar belakangnya harus menggunakannya sebagai acuan wajib yang pada akhirnya berdampak pula pada penilian kualitas lembaga pendidikan melalui akreditasi lembaga. 


\section{E. PENUTUP}

Permasalahan Guru dan Tenaga Kependidikan di sebuah Negara selalu menjadi isu sentral dari masa ke masa. Hal ini dikarenakan Guru sebagai sebuah profesi selalu dipandang sebagai ujung tombak penentu keberhasilah pendidikan suatu bangsa. Permasalahan utama yang kerap muncul dalam berbagai forum diskusi terkait masalah ini adalah masalah kualifikasi dan kompetensi Guru dan pelaksanaan pembelajaran. Menyadari pentingnya permasalahan tersebut berbagai kebijakan dan fasilitas disiapkan untuk mendorong peningkatan kinerja Guru dalam menjalankan tugastugas profesinya. Namun persoalan kunci yang tak kalah pentingnya adalah motivasi dan inisiatif kerja Guru yang dalam data statistik justru mengalami kemunduran paska penerapan kebijakan sertifikasi dan dana insentifnya.

Rendahnya skill penguasaan teknologi terkini menjadi permasalahan serius pula di era informasi yang serba cepat. Karenanya dirasa sangat perlu ke depan, aspek penguasaan IT bagi Guru menjadi salah satu prasyarat Guru Profesional. Jika sebelumnya pemerintah menetapkan 4 kompetensi dasar yang harus dikuasai Guru disamping kualifikasi pendidikan minimal S1 atau D4, maka perlu dikaji secara serius tawaran satu kompetensi baru yang harus dimiliki Guru dan tenaga kependidikan yaitu Kompetensi Penguasaan Teknologi.

\section{DAFTAR PUSTAKA}

Nata, Abuddin, 2012, Managemen Pendidikan:

MengatasiKelemahan

Pendidikan islam di Indonesia, Jakarta : Prenada Media
Mulyana, Aina, 2012, Indikator dan Faktor yang Mempengaruhi Kinerja Guru https://ainamulyana.blogspot.co m/2012/02/kinerja-guru.html

Prastowo, Andi, 2012, Panduan Kreatif Membuat Bahan Ajar Inovatif, Yogyakarta : Diva Press

Pianda, Didi, 2012, Kinerja Guru: kompetensi Guru, motivasi kerja, kepemimpinan kepala sekolah, Sukabumi : CV Jejak

Koswara-Rasto, 2016, Kompetensi dan Kinerja Guru Berdasarkan Sertifikasi Profesi, Jurnal Managemen dan Perkantoran Vol. 1 No. 1, Agustus 2016, hal. 61-71

Mitrani, 1995, Manajemen Sumber Daya Manusia Berdasarkan Kompetensi. (Jakarta : Pustaka Utama Grafiti

Noer, Muhammad, Blended Learning Mengubah Cara Kita Belajar di Masa Depan, https://www.muhammadnoer.c om/blended-learningmengubah-cara-kita-belajar-dimasa-depan/

Damopoli, Muljono, 2007, Potret Pendidikan islam: Perspektif Pembaharuan Pemikiran dan Gerakan Islam Kontemporer di Indonesia, Jurnal Lentera Pendidikan edisi X - Juni, Makasar : UIN Alaudin Makasar, 
Ramayulis, 2008, Ilmu Pendidikan Islam, cet ke 10, Jakarta: Kalam Mulia

Kasali, Rhenald, 2017, Disruption, cetakan keenam, Jakarta : Kompas-Gramedia

Widyawati, Rini, 2012, Implementasi Program Penilaian Kinerja Guru (PKG) Pada Guru SMP dii Dinas Pendidikan, Pemuda, dan Olahraga Kabupaten Sleman, Yogyakarta: Jurnal UNY

Salinan Peraturan Menteri Pendidikan Nasional nomor 16 tahun 2007

Uno, H. B., \& Lamatenggo, N. Teori kinerja dan pengukurannya. (Jakarta: Bumi Aksara, 2012)

Arifin, Zainal, 2012, Evaluasi Pembelajaran, Jakarta : Dirjen Pendis Kemenag

http://bsnp-indonesia.org/standarnasional-pendidikan/

, Apakah Gaji Guru Tinggi

Bisa Perbaiki Kualitas

Pendidikan?

https://irto.id/apakah-gajiguru-tinggi-bisa-perbaikikualitas-pendidikan-daUa , Indeks Pembangunan Manusia, Norwegia No. 1, Indonesia No. 108, https://www.republika.co.id/ber ita/nasional/umum/14/07/24/n9 7x9g-indeks-pembangunanmanusia-norwegia-no-1indonesia-no-108 http://www.kamuskbbi.id/inggr is/indonesia.php? $\mathrm{mod}=$ view\&cl ass\&id=5142-kamus-inggrisindonesia.html , Menyoal Pendidikan Calon Guru,

http://sumberdaya.ristekdikti.go .id/index.php/2017/07/11/meny oal-pendidikan-calon-guru/ , Peringkat dan Capaian PISA Indonesia Mengalami Peningkatan, https://www.kemdikbud.go.id/ main/blog/2016/12/peringkatdan-capaian-pisa-indonesiamengalami-peningkatan 